\title{
A REGIONAL MODEL OF IMPORT-EMPLOYMENT SUBSTITUTION: THE CASE OF TEXTILES
}

\author{
David Henderson and Scott Sanford"
}

\begin{abstract}
An elasticity of textile employment with respect to textile imports is estimated for the nation, two regions, and four local areas. A theoretical labor demand equation is derived which endogenizes textile imports and facilitates direct estimation of import-employment elasticities. The results indicate the textile imports only partially substitute for domestic employment and that the estimated elasticity varies by region. The estimated elasticity was -.27 for the nation and ranged from -.22 to -.31 at the regional level and from -.43 to -.19 for the local analysis. The elasticities are used in an impact analysis to demonstrate the over and under estimation of direct employment loss which occurs when estimates from spatial averages are used.
\end{abstract}

\section{INTRODUCTION}

During the 1980's the United States began to experience increasing trade deficits, which are still particularly acute in the textile sector. The quantity of textile imports increased by 202 percent between 1980 and 1986 while the quantity of exports decreased by 26 percent [Department of Agriculture (1988)]. Over the six year period, U.S. textile employment declined by 142,113 jobs as compared with a decline of 132,230 in the preceding decade of the 1970's [Department of Commerce (1969-1986a)]. Changes in the balance of trade effected domestic textile employment as domestic producers adjusted output to meet the new market conditions.

Domestically, the adoption of new technologies has allowed the substitution of capital for labor in the sector. Automatic chute feeders, shuttleless looms, robotics, and other equipment innovations have contributed to the employment decline in the textile industry. However, the substitution of capital for labor only partially explains the recent large textile employment decline because the value of domestic output also decreased by $15 \%$ during early 1980 's as compared to the 1970's [Department of Commerce (1969-1986b)].

Internationally, competition in the industry increased as the newly developing countries continued to target textiles as an export industry [Center for Industry Policy and Strategy (1984)]. The terms of trade also shifted during the 1980's as the value of the dollar increased. The real value of the dollar increased $90 \%$ against the Chinese currency, $28 \%$ against the Korean currency, $27 \%$ against the

\footnotetext{
Agricultural Economists with the Agriculture and Rural Economy Division and Commodity Economics Division of the Economic Research Service, respectively.
} 
Indian currency, $22 \%$ against Taiwanese currency, and $11 \%$ against the currency in Hong Kong between 1980 and 1985 [Cline (1987), p.60]. Increases in the value of the dollar contributed to the decrease in U.S. textile output because the relative price of imports decreased and the less expensive foreign output was substituted fordomestic output.

The purpose of this paper is to estimate labor demand equations to assess the extent to which textile imports displaced domestic textile workers at the national, regional and local level. The organization of the paper is as follows. Section II develops a theoretical model which integrates export base theory into a regional econometric labor demand equation. Section III describes the data and equations used to estimate a labor demand function for the textile industry. Section IV presents the results of the estimated labor demand equation for the nation, a Piedmont region, and the rest of the country. Section $\mathrm{V}$ presents local estimates of the import-labor substitution in the textile sector of the Piedmont region. Section VI provides a brief summary of the results.

\section{A THEORETICAL LABOR DEMAND MODEL OF TEXTILE IMPORT-LABOR SUBSTITUTION}

The use of derived demand equations from production functions for estimating labor usage in manufacturing was a major development in regional economics during the 1970's [Bolton (1985)]. Two theoretical approaches developed; a traditional approach of desired labor in a perfect labor market and a second theory based on actual labor use in an imperfect labor market where firms hoard labor. Estimation of the dema 1 for labor in the perfect market approach has used the standard functional forms (CES, Cobb-Douglas, translog, linear etc.) and the imperfect market approach has used lagged adjustment models (Koyck, Nerlove, polynomial, etc.).

Previous modeling of the textile sector has used the perfect market approach to estimate the effect of imports on domestic textile output [Dyer (1987)]. The model used in this study utilizes the desired labor market framework to develop a regression which estimates the relationship between foreign imports and domestic textile employment. The specification of a single labor demand equation integrates principles from export base theory into the regional labor demand equation.

The microeconomic input demand function is specified as a function of output and input prices with the optimal labor usage determined by setting the marginal value product of labor equal to the wage rate [Varian (1984)]. In regional modeling the theoretical amount of desired labor use is a function of output, capi- 
tal stock, wage rate, and product price [Bolton (1985), p. 509]. A general theoretical specification takes the following form [Jerrell and Morgan (1988)]:

$$
\operatorname{LnE}_{t}=a_{0}+a_{1} L n Q_{t}+a_{2} L n C_{t}+a_{3} L n W_{t}+a_{4} L n P_{t}+e_{t}
$$

where $\mathrm{E}$ is employment, $\mathrm{Q}$ is a measure of output, $\mathrm{C}$ is a measure of capital stock, $\mathrm{W}$ a measure of the wage rate, $\mathrm{P}$ a measure of output price, and $\mathrm{a}_{\mathrm{i}}$ are parameters. Previous estimation procedures have either omitted some theoretical variables or replaced them with national variables [Bolton (1985)].

Export base theory is theoretically linked to the regional labor demand equation in the measure of output $(\mathrm{Q})$. Export base theory uses an accounting identity to equate regional output $(\mathrm{Q})$ to regional final demand. The regional accounting identity equates total demand for the industry in the region to regional output for regional markets, plus regional output for foreign markets, plus regional output for domestic markets outside the region, minus foreign imports into domestic markets [Norse (1968)]. Thus,

$$
\mathrm{TD}=\mathrm{Q}=\mathrm{Q}_{\mathrm{r}}+\mathrm{Qfe}_{\mathrm{fe}}+\mathrm{Q}_{\mathrm{de}}-\mathrm{Q}_{\mathrm{fi}}
$$

where TD is total demand for the regional output $(Q), Q_{r}$ is regional output for regional markets, $Q_{f e}$ is regional output for foreign markets, $Q_{d e}$ is regional output for domestic markets outside the region, and $Q_{f i}$ is foreign imports into domestic markets.

In the framework of Neoclassical economics the regional accounting identity is the comparative statics equivalent of the equilibrium condition of supply (Q) equaling demand. The regional identity provides a definition of regional output which generalizes the Neoclassical framework to include imports and exports. Within the Neoclassical framework, the inclusion of trade into output is analogous to a whole firm profit analysis with buying and selling of intermediate outputs ${ }^{1}$.

In perfectly competitive markets, an increase in exports ( $\left.Q_{\mathrm{fe}}, Q_{\mathrm{de}}\right)$ either shifts the aggregate total physical product (TPP) curve up (if new investment occurs) or causes the industry to move along the aggregate TPP curve to a higher level of output (if no new investment occurs). Ceteris paribus, the use of the variable input (labor) increases in both cases as total output increases [Varian (1984)]. The increase in exports has the same effect on output as an increase in intermediate selling activities in a whole firm profit analysis.

Conversely, an increases in foreign imports $\left(\mathrm{Q}_{\mathrm{fi}}\right)$ into the domestic market has the opposite effect. The TPP curve for the industry either shifts down (if disinvestment occurs) or, if there is no disinvestment, the industry moves to a lower 
level of output as foreign imports increase. Ceteris paribus, the use of the variable input (labor) decreases in both cases as total output decreases [Varian (1984)]. In this case, imports substitute for domestic output and have the same effect on output as an increase in intermediate buying activities in a whole firm profit analysis. The decrease in regional employment will be directly proportional to the decrease in regional output if the output to labor ratio is constant ${ }^{2}$.

Substituting the regional definition of quantity (equation 2 ) into the general specification of equation 1 yields a theoretical labor demand equation for a region. A theoretical regional labor demand function including all of the elements of regional output could be written as follows:

$$
\begin{aligned}
L_{n} E_{t}=a_{0} & +\left(a_{1} L n Q_{t}+a_{2} L n Q_{f e t}+a_{3} L n Q_{\text {det }}-a_{4} L n Q_{f i t}\right) \\
& +a_{5} \operatorname{LnC} C_{t}+a_{6} L n W_{t}+a_{7} L n P_{t}+e_{t}
\end{aligned}
$$

where $\mathrm{Q}$ (output) in equation 1 has been decomposed into its regional elements $\left(Q_{\mathrm{r}}+\mathrm{Q}_{\mathrm{fe}}+\mathrm{Q}_{\mathrm{de}}-\mathrm{Qff}_{\mathrm{f}}\right)$.

\section{DATA AND MODELS}

Regional output for regional consumption $\left(\mathrm{Q}_{\mathrm{r}}\right)$, regional output for foreign markets $\left(\mathrm{Q}_{\mathrm{fe}}\right)$, and regional output for domestic markets outside the region $\left(\mathrm{Q}_{\mathrm{de}}\right)$ should all be positively related to total textile output and employment. Foreign imports $\left(\mathrm{O}_{\mathrm{fi}}\right)$, on the other hand, should be negatively related to total regional textile output and employment. Collecting the like signed terms yields the following empirical specification:

$$
\operatorname{LnE}_{t}=a_{0}+\left(a_{1} \operatorname{Ln} Q_{d t}+a_{2} \operatorname{Ln} Q_{\text {fit }}\right)+a_{3} \operatorname{LnC} C_{t}+a_{4} L n W_{t}+a_{5} \operatorname{Ln} P_{t}+e_{t}
$$

where $Q$ in equation 3 has been aggregated into two regional output components $\mathrm{Q}_{\mathrm{dt}}\left(\mathrm{Q}_{\mathrm{T}}+\mathrm{Q}_{\mathrm{fe}}+\mathrm{Q}_{\mathrm{de}}\right)$ and $\mathrm{Q}_{\text {fit. }}$. The substitution and collecting of like signed terms facilitates a specification which endogenizes imports and allows direct estimation of an import-labor substitution elasticity in the empirical labor demand equation.

The data used to estimate equation 4 were as follows. E was measured as county level employment in textiles (SIC 22), Qdt was measured as U.S. domestic textile output in pounds, Qfit was measured as U.S. textile imports in pounds, C was measured as U.S. investment in textile plants and equipment in 1982 dollars, W was measured as the U.S. textile wage rate in 1982 dollars, P was measured as 
an index of textile market prices, $a_{i}$ are parameters to be estimated, $t$ is year (1969-1986), and e is a normally distributed random error term.

Seven models were estimated using equation 4 . The first model estimated an import-labor substitution elasticity for the nation. The second and third models estimated regional import-labor substitution elasticities for two regions in the country. The last four models estimated import-labor substitution elasticities for local areas in the Piedmont region. All equations were estimated in natural logs using time series Ordinary Least Squares ${ }^{3}$.

Equation 4 uses national variables to hold total domestic output, investment, change in textile price, and textile wages constant while estimating an importlabor substitution elasticity. Holding domestic investment and wages constant controls for the substitution effect of replacing capital for labor and its contribution to the decline of textile employment. The theoretical signs on output price, physical output, and plant investment are positive and the sign on equipment investment and the price of the input (labor) is negative ${ }^{4}$.

The sign on foreign imports into the national market is an empirical question. If the textile imports and domestic output are both increasing due to an increase in domestic demand for textiles, then the empirical relationship between competitive imports and domestic employment could be positive. If the imports are substitutes for domestic textile output, then the empirical relationship could be negative [Dyer (1987)].

Given an estimated negative sign, the magnitude of the elasticity will reflect the degree of substitution between textile employment and foreign imports into the domestic market. An estimated elasticity close to -1 implies the imports are near perfect substitutes for domestic textile labor. If the estimated elasticity is between 0 and -1 it implies partial substitution of competitive imports for domestic textile labor.

The theoretical ceteris paribus conditions hold at the regional and local level only if the competitive position of the industry between regions did not change over the period. If the industry in any region had a competitive advantage relative to the industry in other regions the estimated labor demand equation for that region should be statistically discernable from the other regions. Contemporary studies show the effect of inter-regional plant relocations on regional employment was minimal as only 2 percent of all manufacturing plants relocated outside the county they were initially located in and the relocations effected only 1.6 percent of all manufacturing employment [Miller (1984)]. 


\section{NATIONAL AND REGIONAL RESULTS}

The estimated elasticities of the independent variables with respect to textile employment and related statistical information for the nation and the two regions are provided in Table 1. No significant difference between the estimated regional and national equations implies the labor demand curve for the textile industry in the two regions is the same as the labor demand curve for the industry in the nation. It follows that the structure of textile production in the two regions is statistically homogeneous with respect to the distribution of production and plant size.

TABLE 1

Estimated National and Regional Textile Labor Demand Equations

\begin{tabular}{|c|c|c|c|}
\hline $\begin{array}{l}\text { Model/ } \\
\text { Variables }\end{array}$ & $\begin{array}{l}\text { National } \\
\text { Equation }\end{array}$ & $\begin{array}{l}\text { Piedmont Region } \\
\text { Equation }\end{array}$ & $\begin{array}{l}\text { Rest of the Country } \\
\text { Equation }\end{array}$ \\
\hline Intercept & $\begin{array}{l}7.40001^{\mathrm{a}} \\
(2.2353)\end{array}$ & $\begin{array}{c}7.60974^{\mathrm{a}} \\
(2.0651)\end{array}$ & $\begin{array}{c}5.94649^{\mathrm{b}} \\
(3.0767)\end{array}$ \\
\hline Output & $\begin{array}{l}.30547^{b} \\
(.1464)\end{array}$ & $\begin{array}{l}.26427^{c} \\
(.1353)\end{array}$ & $\begin{array}{l}.34211^{c} \\
(.1644)\end{array}$ \\
\hline Imports & $\begin{array}{l}-.27215^{\mathrm{a}} \\
(.0593)\end{array}$ & $\begin{array}{l}-.22276^{2} \\
(.0547)\end{array}$ & $\begin{array}{l}-.31462^{a} \\
(.0666)\end{array}$ \\
\hline Investment & $\begin{array}{l}.60896^{\mathrm{a}} \\
(.0800)\end{array}$ & $\begin{array}{l}.50352^{\mathrm{a}} \\
(.0705)\end{array}$ & $\begin{array}{l}.69713^{\mathrm{a}} \\
(.0898)\end{array}$ \\
\hline Wages & $\begin{array}{l}.77784 \\
(.8198)\end{array}$ & $\begin{array}{l}.50600 \\
(.7574)\end{array}$ & $\begin{array}{l}.99904 \\
(.9208)\end{array}$ \\
\hline Prices & $\begin{array}{l}-.08554 \\
(.0566)\end{array}$ & $\begin{array}{l}-.04735 \\
(.0522)\end{array}$ & $\begin{array}{l}-.11621 \\
(.06352)\end{array}$ \\
\hline $\mathrm{R}^{2}$ & .9489 & .9321 & .9529 \\
\hline
\end{tabular}

Reported coefficients are elasticities.

Standard errors are in parentheses.

Significant at the .01 level.

b Significant at the .05 level.

c Significant at the .10 level.

The estimated elasticity of textile imports with respect to textile employment for the nation, the Piedmont region, and the rest of the country was $-.27,-.22$ and -.31 , respectively. Dyer $(1987$, p. 31$)$ estimated the elasticity of imports with respect to national domestic textile output to be -.24 . The two estimates are con- 
sistent and confirm only partial substitution of imports for domestic textile output and employment.

The estimated national elasticity of textile imports with respect to textile employment is an average of the two estimated regional elasticities ${ }^{5}$. The estimated national elasticity is greater than the estimated Piedmont elasticity and less than the rest of the country elasticity. Use of the national elasticity in a direct impact analysis of employment loss from textile imports in the regions is inaccurate because it overestimates the direct loss of employment in the Piedmont region and underestimates the direct loss of employment in the rest of the country (Table 2).

TABLE 2

National and Regional Estimates of Direct Textile Employment Losses

\begin{tabular}{|c|c|c|c|c|c|}
\hline & \multirow[b]{2}{*}{$\begin{array}{c}\text { Total } \\
\text { Employment } \\
\text { Loss } \\
(1980-86)\end{array}$} & \multicolumn{2}{|c|}{ National Estimates } & \multicolumn{2}{|c|}{ Regional Estimates } \\
\hline & & $\begin{array}{l}\text { Percentage } \\
\text { attributed } \\
\text { to imports }\end{array}$ & $\begin{array}{l}\text { Emp. Loss } \\
\text { attributed } \\
\text { to imports }\end{array}$ & $\begin{array}{l}\text { Percentage } \\
\text { attributed } \\
\text { to imports }\end{array}$ & $\begin{array}{l}\text { Emp. loss } \\
\text { attributed } \\
\text { to imports }\end{array}$ \\
\hline Regionc & 59,119 & .54974 & 32,500 & .44997 & 26,601 \\
\hline Region $^{d}$ & 82.994 & .54974 & 45.625 & .63533 & 52.745 \\
\hline Nation & 142,113 & .54974 & 78,125 & & 79,346 \\
\hline
\end{tabular}

is the estimated elasticity multiplied by the percentage change in imports 1980-86.

b is the percentage attributed to imports times the total decline in employment 1980-86.

c is the 108 contiguous counties in the Piedmont region.

$d$ is the rest of the counties in the country reporting employment in SIC 22.

The national estimate of employment loss from textile imports was 2 percent $(1,221)$ less than the weighted regional estimates of direct employment loss. The national estimate of employment loss from textile imports in the Piedmont region was overestimated by 22 percent $(5,899$ jobs). Conversely, the national estimate of employment loss from textile imports in the rest of the country was underestimated by 13 percent $(7,120$ jobs).

\section{LOCAL RESULTS}

The four local equations were estimated from 108 contiguous counties in the Piedmont region from southem Virginia to northeast Alabama where textile mill employment is concentrated [Starbird (1987)]. The local estimates reflect the import-employment elasticity along different segments of the industry derived 
demand curve for labor ${ }^{6}$. Statistically, the local estimates decompose the Piedmont regional elasticity into four local elasticity estimates.

The estimated local elasticities and related statistical information are in Table 3. The estimated local equations were not statistically different than the regional or national equations. It follows that the local structure of textile production is statistically homogeneous with the structure of textile production in the region and the country.

TABLE 3

Estimated Local Textile Labor Demand Equations

\begin{tabular}{|c|c|c|c|c|}
\hline \multirow{2}{*}{$\begin{array}{l}\text { Model/ } \\
\text { Variables }\end{array}$} & \multicolumn{4}{|c|}{ Local Areas } \\
\hline & $R=1$ & $\mathrm{R}=2$ & $R=3$ & $R=4$ \\
\hline Intercept & $\begin{array}{c}5.81197 \\
(4.0872)\end{array}$ & $\begin{array}{c}5.44220^{b} \\
(2.0651)\end{array}$ & $\begin{array}{l}5.09409^{c} \\
(3.0767)\end{array}$ & $\begin{array}{c}8.00213^{\mathrm{a}} \\
(1.7839)\end{array}$ \\
\hline Output & $\begin{array}{c}.29456 \\
(.1464)\end{array}$ & $\begin{array}{l}.20132 \\
(.1407)\end{array}$ & $\begin{array}{l}.36015^{\mathrm{c}} \\
(.1644)\end{array}$ & $\begin{array}{l}.24527^{b} \\
(.1168)\end{array}$ \\
\hline Imports & $\begin{array}{l}-.43518^{\mathrm{a}} \\
(.1018)\end{array}$ & $\begin{array}{l}-.19574^{\mathrm{a}} \\
(.0569)\end{array}$ & $\begin{array}{l}-.26051^{\mathrm{a}} \\
(.0666)\end{array}$ & $\begin{array}{l}-.19653^{\mathrm{a}} \\
(.0473)\end{array}$ \\
\hline Investment & $\begin{array}{l}.42027^{\mathrm{a}} \\
(.0800)\end{array}$ & $\begin{array}{l}.43282^{\mathrm{a}} \\
(.0769)\end{array}$ & $\begin{array}{l}.61107^{\mathrm{a}} \\
(.0898)\end{array}$ & $\begin{array}{l}.49403^{\mathrm{a}} \\
(.0638)\end{array}$ \\
\hline Wages & $\begin{array}{l}1.52813 \\
(1.499)\end{array}$ & $\begin{array}{l}1.43692 \\
(.7877)\end{array}$ & $\begin{array}{r}.40008 \\
(1.0265)\end{array}$ & $\begin{array}{l}-.20706 \\
(.6543)\end{array}$ \\
\hline Prices & $\begin{array}{l}-.03564 \\
(.1034)\end{array}$ & $\begin{array}{l}.02064 \\
(.0543)\end{array}$ & $\begin{array}{l}-.09496 \\
(.0781)\end{array}$ & $\begin{array}{l}-.05952 \\
(.0451)\end{array}$ \\
\hline $\mathbf{R}^{2}$ & .7763 & .8206 & .9326 & .9556 \\
\hline
\end{tabular}

Reported coefficients are elasticities.

Standard errors are in parentheses.

Significant at the .01 level.

${ }^{\mathrm{b}}$ Significant at the .05 level.

c Significant at the .10 level.

$R=1$, average textile employment equaled 524 persons per county.

$R=2$, average textile employment equaled 2,581 persons per county.

$R=3$, average textile employment equaled 6,524 persons per county.

$R=4$, average textile employment equaled 15,625 persons per county.

The estimated elasticity of textile imports with respect to local textile employment ranged from -.43 in the counties with the lowest average employ- 
ment to -.19 in the counties with the highest average employment. The estimated elasticity for the Piedmont region represents an average of the local elasticities in the region ${ }^{7}$. Use of the national or regional average elasticity in a local impact analysis of direct employment loss from textile imports is inaccurate because the computations overestimate the direct employment loss in some Piedmont counties and underestimate the loss in others (Table 4).

The national estimate of employment loss from textile imports was 16 percent (4,598 jobs) more than the local estimates of employment loss and the Piedmont regional estimate was 5 percent $(1,296$ jobs) less than the local estimates. The error in the national estimate of local employment loss from textile imports was three times as large as the error in the Piedmont regional estimates. The regional estimate, although more accurate than the national estimate, still tended to overestimate the direct employment loss in some local areas $(R=2, R=4)$ and under estimate the local direct employment loss in other local areas $(R=1, R=3)$.

TABLE 4

National, Regional, and Local Estimates of Direct Textile Employment Losses

\section{National and Regional Estimates Local Estimates}

\begin{tabular}{lccccc} 
& $\begin{array}{c}\text { Total } \\
\text { Employment } \\
\text { Loss } \\
(1980-86)\end{array}$ & $\begin{array}{c}\text { Emp. Loss } \\
\text { attributed } \\
\text { to imports }\end{array}$ & $\begin{array}{c}\text { Emp. Loss } \\
\text { attributed } \\
\text { to imports }\end{array}$ & $\begin{array}{c}\text { Percentage } \\
\text { attributed } \\
\text { to imports }\end{array}$ & $\begin{array}{c}\text { Emp. loss } \\
\text { attributed } \\
\text { to imports }\end{array}$ \\
\hline $\mathbf{R = 1}$ & 3,334 & 1,833 & 1,500 & .87906 & 2,931 \\
$\mathbf{R}=2$ & 7,834 & 4,307 & 3,525 & .39537 & 3,097 \\
$\mathrm{R}=3$ & 20,435 & 11,234 & 9,195 & .53550 & 10,943 \\
& & & & & \\
$\mathrm{R}=4$ & $\underline{27.466}$ & 15.099 & 12.359 & .39699 & 10.904
\end{tabular}

Total

59,119

32,473

26,579

27,875

\footnotetext{
is the estimated elasticity multiplied by the percentage change in imports 1980-86.

$\mathrm{b}$ is the percentage attributed to imports times the total decline in employment 1980-86.

c is based on national elasticity estimate.

d is based on elasticity estimate from the 108 contiguous Piedmont counties.

$\mathbf{R}=1$, average textile employment equaled 524 persons per county.

$R=2$, average textile employment equaled 2,581 persons per county.

$R=3$, average textile employment equaled 6,524 persons per county.

$R=4$, average textile employment equaled 15,625 persons per county.
} 


\section{SUMMARY AND CONCLUSIONS}

The estimated regional textile import-employment elasticities ranged from -.22 in the Piedmont region to -.31 in the rest of the country with a national average elasticity of -.27 . The estimated local textile import-employment elasticity ranged from -.43 to -.19 within the Piedmont region. The results indicate that textile imports only partially substitute for domestic employment and that the substitution varied between regions and local economies.

The estimated direct employment impact represents the first round effect of employment loss in the regions of interest. The regions also experienced subsequent secondary indirect loses of employment in other sectors which are linked to the textile sector. The total employment multiplier (direct and indirect) could be substantially larger than the direct estimate in this paper.

The estimates illustrate an important principle of spatial economics. Areal data represent spatial averages across geographic units and estimates derived from them are average coefficients through space. The procedure outlined in this paper provides a method which can be used to derive more accurate regional and local estimates.

\section{ENDNOTES}

1. Imports and exports enter an industry aggregate profit function like intermediate selling and buying activities enter an individual whole firm profit function. The long run equimarginal principle for the labor factor at the regional level implies $P_{w} / P_{y}=M P_{r}=M P P_{f}=P_{w} / P_{y}$, where the first price ratio and marginal physical product (MPP) refer to the region of interest and the second MPP and price ratio refer to the foreign competitor.

2. A 95 percent confidence interval was employed to test for differences in the output to labor ratio over two periods. We tested the output to labor ratio for the 1969-1979 period against the 1980-1986 period and failed to reject the hypothesis of a constant output to labor ratio. The 1969-79 period had a mean and variance of 5.65226 and .20386 . The 1980-86 period had a mean and variance of 6.27338 and .68611 .

3. Chow parameter stability tests indicate no structural difference in the estimated equations. Tests for first order autocorrelation failed to reject the hypothesis of no first order autocorrelation.

4. The use of the labor input will be positively related to the level of plant investment because plant investment represents new output capacity which requires more of the variable labor input. The use of the labor input will be nega- 
tively related to the level of equipment investment because new equipment substitutes for labor in the production process. The estimated sign on plant and equipment investment is an empirical matter which is determined by which kind of investment has the strongest effect on the specified labor demand equation.

5. The share of total U.S. textile employment in the Piedmont region was .45411 and the share of total employment for the rest of the country was .54589 . The sum of the estimated regional import-labor elasticities weighted by the percentage of total U.S. textile employment in the two regions equaled the estimated import-labor elasticity for the nation with a rounding error at the fourth decimal point. $(.45411)(-.22276)+(.54589)(-.31462)=-.27290$

6. Four county groups were delineated on the basis of average textile employment over the period. The case of low county employment corresponds to the top of the industry derived demand curve for labor where the marginal physical product of a unit of additional labor is relatively high in textile production. The case of high county employment corresponds to the bottom portion of the industry derived demand curve for labor where the marginal physical product of a additional unit of labor is approaching zero.

7. The share of total Piedmont region employment by local group was $R=1$ (.04266), $R=2$ (.28673), $R=3$ (.27797), and $R=4$ (.39264). The sum of the estimated local import-labor elasticities weighted by the percentage of total Piedmont textile employment in the local areas equaled the estimated import-labor elasticity for the Piedmont region with a rounding error at the third decimal point. $(.04266)(-.43518)+(.28673)(-.19574)+(.27797)(-.26051)+(.39264)(-.19653)=$ -.22425 .

\section{REFERENCES}

Bolton, Roger. "Regional Econometric Models." Journal of Regional Science. 25 (1985). 495-520.

Center for Industry Policy and Strategy " World Industry Studies; The Global Textile Industry " Center for Industry, Policy, and Strategy. University of South Carolina, 1984.

Cline, R. " The Future of World Trade in Textiles and Apparel." Institute for International Economics. 1987.

Dyer, C. " A Partial Equilibrium Analysis of the Initial Output and Employment Impacts of Textile Imports into the United States." National Textile Consultant. 1 (1987) 26-34.

Jerrel, M. and J. Morgan. "Modeling Labor Demand in a State Econometric Model." The Review of Regional Studies. 18 (1988) 31-40. 
Miller, James P. "Manufacturing Relocations in the United States, 1969-1975." in Plant Closings: Public or Private Choices? edited by Richard B. Mckenzie, CATO Institute, 1984.

Norse, H.O. Regional Economics. St. Louis, Missouri: McGraw Hill Book Company, 1968.

Starbird, I. The U.S. Cotton Industry. National Economic Division, E.R.S., U.S.D.A., 1987.

U.S. Department of Agriculture. Cotton and Wool: Situation and Outlook Yearbook. Commodity Economics Division, E.R.S., 1988.

U.S. Department of Commerce. Bureau of Economic Analysis. Economic Information Series. U.S. Government Printing Office. 1969-86a.

- Bureau of Economic Analysis. Survey of Current Business U.S. Government Printing Office. 1969-86b.

Varian, Hal. Microeconomic Analysis. New York, N.Y.: W. W. Norton Company, 1984. 